\title{
Evaluation of Anticancer Potential of Vitus vinifera Seed Against Breast Cancer Cells - MDA-MB-231
}

\author{
Kiruthika Dhanraj, Renuka Saravanan, Sheik Abdulla Shahul Hameed, Sivakumar Ramalingam*
}

\section{Kiruthika Dhanraj, Renuka Saravanan, Sheik Abdulla Shahul Hameed, Sivakumar Ramalingam*}

Department of Chemistry and Biosciences, SASTRA Deemed to be University, Srinivasa Ramanujam Centre, Kumbakonam 612001, Tamil Nadu, INDIA.

\section{Correspondence}

\section{Sivakumar Ramalingam}

Department of Chemistry and

Biosciences, SASTRA Deemed to be

University, Srinivasa Ramanujam Centre,

Kumbakonam 612001, Tamil Nadu, INDIA

Phone no: 9751545725

E-mail: rsiva@src.sastra.edu

History

- Submission Date: 03-01-2020;

- Review completed: 16-03-2020;

- Accepted Date: 11-04-2020.

DOI : 10.5530/pj.2020.12.150

Article Available online

http://www.phcogj.com/v12/i5

\section{Copyright}

(C) 2020 Phcogj.Com. This is an openaccess article distributed under the terms of the Creative Commons Attribution 4.0 International license.

\begin{abstract}
Objective: The aim of the present research is to evaluate the anti-cancer effect of Vitus vinifera seed on MDA-MB-231 cell line. Methods: The Vitus vinifera (Grape) seed were dried, powdered and subjected to methanol, chloroform and ethyl acetate extraction by cold maceration followed by preliminary phytochemical screening. The extracts of Vitus vinifera seed were subjected to assess anti-oxidant status, anti-proliferative activity by MTT assay, GC-MS analysis and apoptotic effect by determining LDH activity on MDA-MB-231. Results: Results indicated that methanolic extract of grape seed showed appreciable anti-oxidant and anti-cancer potential compared with other two extracts. GC-MS mass spectrum of methanolic extract of seed revealed the presence of Dotriacontane, Linoleic acid and Decanoic acid ethyl ester, 1,2,3, propenetriol, monocetate, and Dichloro methyl propane sulfone were detected. Conclusion: The data obtained in this work could be useful as a chemical standard in checking the genuineness of this plant source. Data of the results further depicted that the selected traditional Vitus vinifera seed could be used not only as a potential anti-cancer and good antioxidant.
\end{abstract}

Key words: Vitus vinifera seed, MDA-MB-231, MTT assay, GC-MS analysis.

\section{INTRODUCTION}

Medicinal plants continue to play a central role in the healthcare system of large proportions of the world's population. ${ }^{1}$ Medicinal plants supply a major source for traditional and modern medicines. Herbs with medicinal values are safer when compared to the modern treatments like radiotherapy and chemotherapy. Herbs are the potential sources for cancer treatment due to their bioactive compounds for discovering new drugs. ${ }^{2}$ Dietary phytochemicals have appeared as advantageous agents for the prevention and therapy of cancer because they have no/less side effects and low toxicity compared to synthetic drugs. ${ }^{3}$

Breast cancer is the heterogeneous cancer which is frequently occurring cancer in women worldwide. Breast cancer is characterized by the uncontrolled growth of abnormal cells in the milk producing glands of the breast. ${ }^{4}$ It is the most common cancer in women both in the developed and less developed world and it is estimated that worldwide over 508 000 women died in 2011 due to breast cancer. ${ }^{5}$ In addition, 63,410 cases of in situ breast carcinoma will be diagnosed among women.

Vitis vinifera (Grapes) represented in (Figure 1) belonging to the Vitaceae family, originated in Western Asia and Europe. It is a non-climacteric fruit that grows on the perennial and deciduous woody climbing vine. Grapes is a cross pollinated vine with simple, lobed, cut or toothed leaves (seldom compound) with racemes of greenish flowers, the fruit consisting of watery or fleshy pulp, stones and skin, four-seeded. ${ }^{6}$ Grapes can be eaten as fresh or used for making jam, juice, jelly,

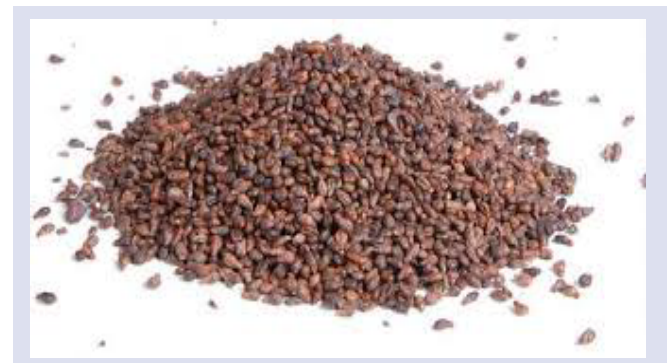

Figure 1: Vitis vinifera seed.

vinegar, wine, grape seed extracts and grape seed oil. Approximately $71 \%$ of world grape production is used for wine, $27 \%$ as fresh fruit, and $2 \%$ as dried fruit. However, in India, $90 \%$ of the grape is used for table purpose, even though wine making has made strides. The rest of the grape is used mostly for raisin. ${ }^{7}$ Grape seed extract has anti-oxidant, cardiovascular effects, hepatoprotective, anti-bacterial anti-viral and anticarcinogenic effects. Hence, this study was aimed to find potential anti-cancer activity of selected Vitis vinifera seed against MDA-MB-231 cell lines.

\section{MATERIALS AND METHODS}

\section{Collection of seed material}

Grapes were purchased and seeds were separated. The seeds were dried in a shade, ground well in an electric blender, and stored in the air tight container for further use.

\section{Preparation of seed extract}

Vitis vinifera seed were dried and powdered, 25gm was taken separately for methanol, $25 \mathrm{gm}$ was taken 
for chloroform and 25g, was taken for ethyl acetate extract. The extraction procedure was carried out by cold maceration method. The preliminary phytochemical investigation was carried out for the presence of bioactive compounds according to the standard method given by Harbone. ${ }^{8}$

\section{MDA MB-231 culture}

The Human Triple Negative Breast cancer cells (MDA MB-231) were purchased from the National Center for Cell Sciences (NCCS), Pune, India. The cancer cells were maintained in Leibovitz-15 +FCS medium (L-15+FCS) supplemented with $2 \mathrm{mM}$ l-glutamine and balanced salt solution (BSS) adjusted to contain $1.5 \mathrm{~g} / \mathrm{L}$ Na2CO3, $0.1 \mathrm{mM}$ nonessential amino acids, $1 \mathrm{mM}$ sodium pyruvate, $2 \mathrm{mM}$ l-glutamine, $1.5 \mathrm{~g} / \mathrm{L}$ glucose, $10 \mathrm{mM}$ (4-(2-hydroxyethyl)-1-piperazineethane sulfonic acid) (HEPES) and 10\% fetal bovine serum (GIBCO, USA). Penicillin and streptomycin $(100 \mathrm{IU} / 100 \mu \mathrm{g})$ were adjusted to $1 \mathrm{~mL} / \mathrm{L}$. The cells were maintained at $37{ }^{\circ} \mathrm{C}$ with $5 \% \mathrm{CO} 2$ in a humidified $\mathrm{CO} 2$ incubator. ${ }^{9}$

\section{ANTIOXIDANT ASSAY}

Antioxidant assay was carried out by the methods of Aishwarya, et al..$^{10}$ The free radical scavenging activity of the fraction was measured in vitro by 1,1 diphenyl- 2- picrylhydrazyl (DPPH) assay. About $0.3 \mathrm{Mm}$ solution of DPPH in 95\% methanol was prepared and $1 \mathrm{ml}$ of this solution was added to $3 \mathrm{ml}$ of the fraction dissolved in chloroform, methanol and ethyl acetate at different concentration. The mixture was shaken and allowed to stand at room temperature for 30 minutes and the absorbance was measured at $515 \mathrm{~nm}$ in a colorimeter. The percentage of the free radical scavenging activity at different concentration was determined.

The antioxidant activity was expressed as

$\%$ of disappearance $=\mathrm{x} 100($ Control - Sample $)$

\section{Cytotoxic assay using MTT assay}

The inhibitory concentration (IC50) value was evaluated by method of Johan, et al. ${ }^{11}$ using an MTT [3-(4, 5- dimethylthiazol-2-yl)-2, 5-diphenyltetrazolium bromide] assay. The cells were grown $\left(1 \times 10^{4}\right.$ cells/well) in a 96 -well plate for $48 \mathrm{~h}$ in to $85 \%$ confluence. The medium was replaced with fresh medium containing serially diluted compound, and the cells were further incubated for $48 \mathrm{~h}$. The culture medium was removed, and $100 \mu \mathrm{L}$ of the MTT [3-(4, 5-dimethylthiozol2-yl)-3, 5-diphenyl tetrazolium bromide] (Hi-Media) solution was added to each well and incubated at $37{ }^{\circ} \mathrm{C}$ for $4 \mathrm{~h}$. After removal of the supernatant, $50 \mu \mathrm{L}$ of DMSO/Iso propanol was added to each of the wells and incubated for 10 min to solubilize the Formosan crystals. The optical density was measured at $620 \mathrm{~nm}$ in an ELISA multiwell plate reader (ThermoMultiskan EX, USA).

The value was used to calculate the percentage of viability using the following formula.

\section{GC-MS Analysis}

\section{Instruments and chromatographic conditions}

Identification of bioactive components by GC-MS Analysis was carried out by method of Syed and Khushnuma. ${ }^{12}$ GC-MS analysis of the extract was carried out with GC-MS Clarus 500 Perkin Elmer system and gas chromatograph interfaced to a mass spectrometer (GC-MS) employing the following condition, Column Elite -1 fused silica capillary column $(30 \mathrm{~mm} \times 0.25 \mathrm{~mm} \mathrm{ID} \times 1 \mathrm{mdf}$, composed of $100 \%$ Dimethyl poly silaxane ), operating in electron impact mode at $70 \mathrm{eV}$, Helium (99.999\%) was used as a carrier gas at a constant flow of $1 \mathrm{ml} / \mathrm{min}$ and an injection volume of 0.5 was employed (split ration of 10,1 ), injector temperature $250^{\circ} \mathrm{C}$, ion source temperature was $280^{\circ} \mathrm{C}$. The oven temperature was programmed from $110^{\circ} \mathrm{C}$ (isothermal for $2 \mathrm{~min}$ ), with an increase of $10^{\circ} \mathrm{C} / \mathrm{min}$, to $200^{\circ} \mathrm{C}$ then $5 \mathrm{C} / \mathrm{min}$ to $280^{\circ} \mathrm{C}$ ending with a 9 minute, isothermal at $280^{\circ} \mathrm{C}$. Mass spectra were taken at $70 \mathrm{eV}$, a scan interval of 0.5 seconds and fragments from 40 to 550 .

\section{Lactate dehydrogenase leak assay}

LDH leakage assay was carried out using LDH cytotoxicity detection kit by Sigma Aldrich Inc., USA, according to protocol in the user's manual. ${ }^{13}$ To determine IC50, different concentrations of herbal extracts were incubated with $100 \mu \mathrm{l}$ of DAL and MDA-MB 231 cell suspensions having $1 \times 10^{6} \mathrm{cell} / \mathrm{ml}$ in 96 well plates and incubated at $37^{\circ} \mathrm{C}$ for $4 \mathrm{hrs}$ in $5 \% \mathrm{CO}_{2}$ atmosphere. All the control and test substances were tested in triplicates and mean \pm SEM of the absorbance values were recorded to calculate the cytotoxicity. LDH leakage (\%) related to control wells containing cell culture medium without extracts was calculated by

[A] test / [A] control X100.

Where $[\mathrm{A}]$ test is the absorbance of the test sample and $[\mathrm{A}]$ control is the absorbance of the control sample.

\section{RESULTS}

\section{Preliminary phytochemical analysis}

Qualitative analysis of phytoconstituents of the methanol, ethyl acetate, and chloroform extract of Vitis vinifera seeds are represented in Table 1. Methanol extract of Vitis vinifera contains terpenoids, steroids, tannins, glycosides, phenols, anthraquinones, proteins and carbohydrates. The ethyl acetate extract of Vitis vinifera contains alkaloids, flavonoids, terpenoids, steroids, tannins, glycosides, phenols, anthraquinones, proteins and carbohydrates. The chloroform extract of Vitis vinifera contains alkaloids, terpenoids, steroids, tannins, glycosides, phenols, anthraquinones, proteins and carbohydrates.

\section{Antioxidant assay}

DPPH (1, 1 diphenyl 2- picraylydrazly) is considered as a stable radical because of the paramagnetisum conferred by its odd electron (decoloration of the spare electron over the molecule as a whole). The solution (in absolute ethanol) appears as a whole violet color due to strong absorption band. DPPH radical can accept an electron or hydrogen radical to become a strong diamagnetic molecule and has a pale violet. Figures 2-4 represents the free radical scavenging capacity of the antioxidants molecules of three extracts namely the methanol, chloroform and ethyl acetate extract of the Vitis vinifera seeds. Of the three extracts ethyl acetate showed free radical scavenging effect.

\section{Cytotoxic assay}

MTT assay has been most widely used in different cancers, and is sensitive, accurate and efficient in the in vitro evaluation of anticancer or immunological agent prior to preclinical and clinical testing. ${ }^{14}$ Figure 5 represent cytotoxic effect of methanol, chloroform and ethyl acetate extract of Vitis vinifera seed on MDA MB 231 cell line. The $\mathrm{IC}_{50}$ value of methanol, chloroform and ethyl acetate of Vitis vinifera seed was found to be $23 \pm 1.5,30 \pm 0.5$ and $34 \pm 0.5$ respectively.

\section{GC-MS analysis}

Fragmentation pattern of few compounds were identified in the Vitis vinifera extract through GC-MS analysis is given in the Table 2 and Gas chromatography mass spectrum were represented in Figure 6 . The list of the compounds are Dotriacontane (CAS), Neroine, 4a,5-dihydro, Octadecane 3-ethyl-5-(2-ethylbutyl)-, Tetratetracontane (CAS), Linoleic acid ethyl ester, 9,12-Octadecaadienoic acid, methyl ester, 9,12-Octadecaadienoic acid(Z,Z)-,methyl ester, 5-(hydroxyl methyl)- 
Table 1: Preliminary phytochemical screening of the various extracts of the Vitis vinifera seeds.

\begin{tabular}{cccc} 
Phytoconstituents & $\begin{array}{c}\text { Methanol } \\
\text { extract }\end{array}$ & $\begin{array}{c}\text { Chloroform } \\
\text { extract }\end{array}$ & $\begin{array}{c}\text { Ethyl acetate } \\
\text { Extract }\end{array}$ \\
\hline Alkaloids & + & - & + \\
Flavonoids & + & - & - \\
Terpenoids & + & + & + \\
Steroids & + & + & + \\
Saponins & - & + & + \\
Tannins & + & + & + \\
Glycosides & + & + & + \\
Phenols & + & + & + \\
Anthraquinones & + & + & + \\
Protein & + & + & + \\
Carbohydrates & + & & + \\
\hline
\end{tabular}

(+) Presence (-) Negative

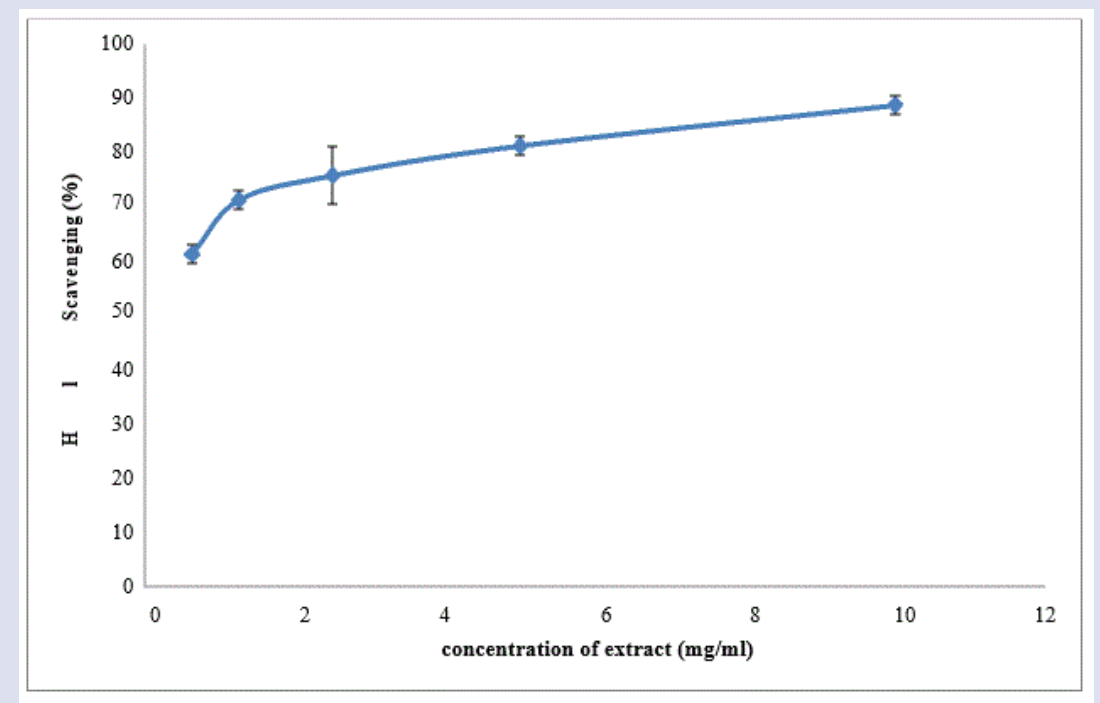

Figure 2: Antioxidant potential of methanolic extract of Vitis vinifera seeds.

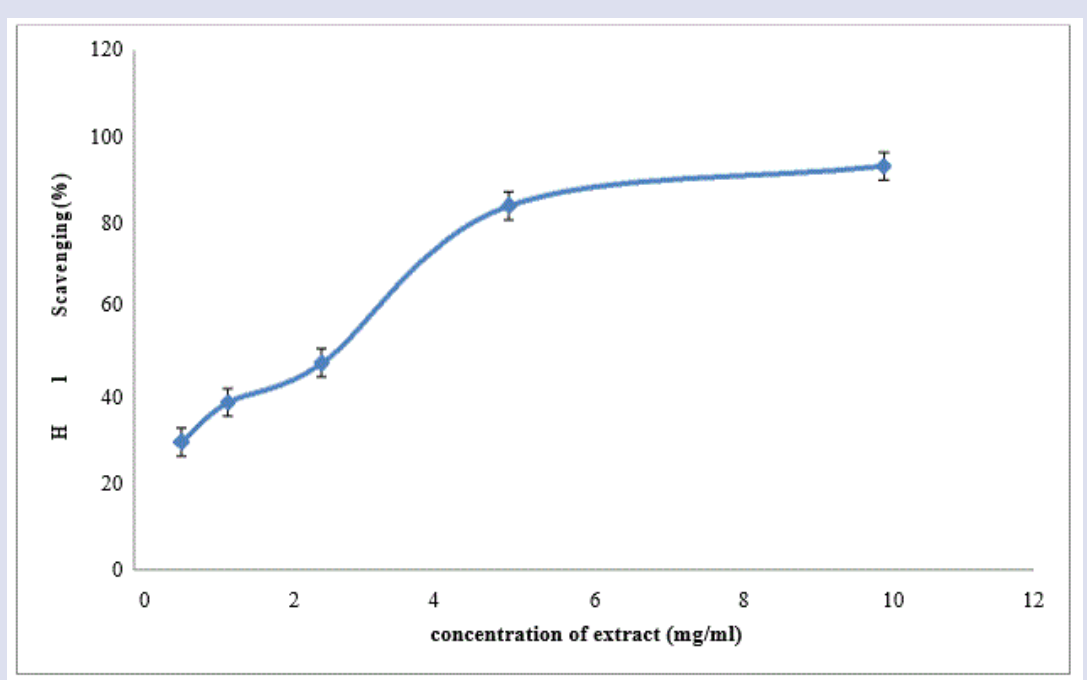

Figure 3: Antioxidant potential of chloroform extracts of Vitis vinifera seeds. 


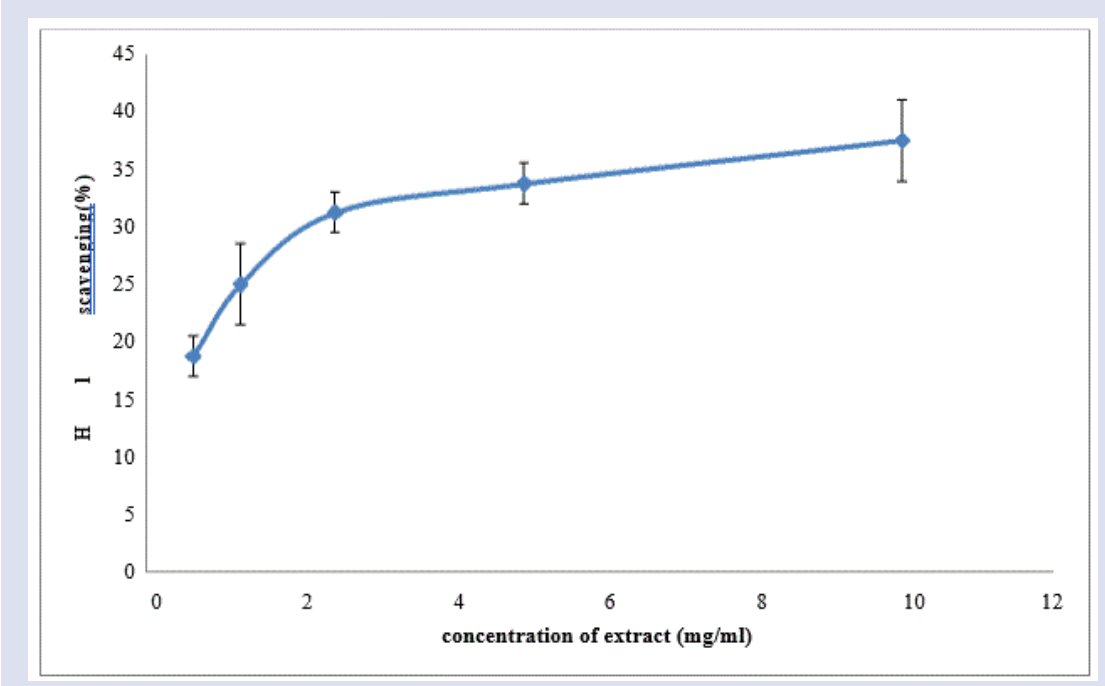

Figure 4: Antioxidant potential of ethyl acetate extracts of Vitis vinifera seeds.
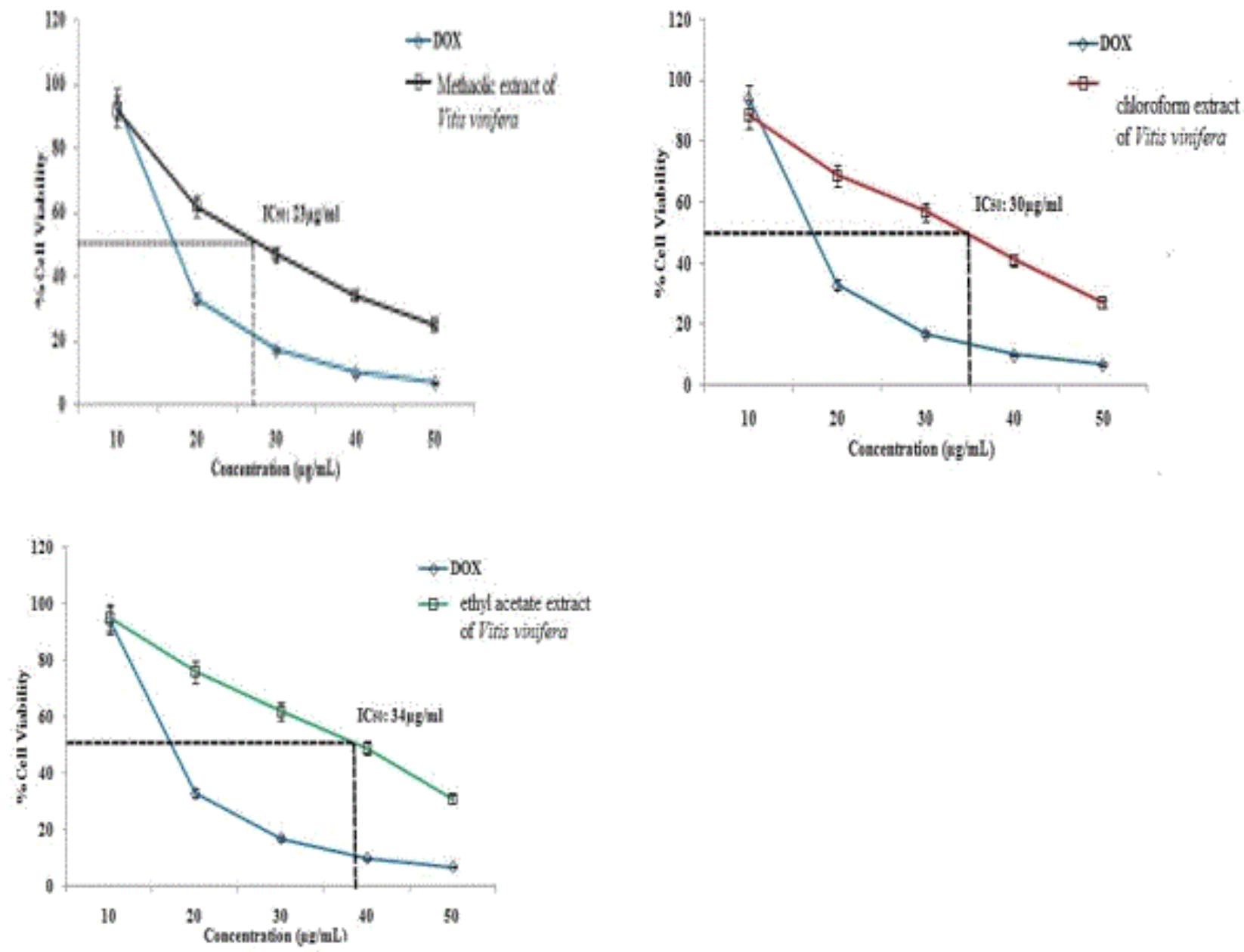

Figure 5: Cytotoxic effect of different extract of Vitis vinifera on MDA MB-231 cell line. 
Table 2: Phytoconstituents of methanolic extract of Vitis vinifera identified by GC-MS.

\begin{tabular}{|c|c|c|c|c|}
\hline Compound name & Probability & Molecular formula & Molecular weight & Area \% \\
\hline Dichloro methyl propane sulfone & 35.88 & $\mathrm{C} 4 \mathrm{H} 8 \mathrm{C} 12 \mathrm{O} 2 \mathrm{~S}$ & 190 & 0.72 \\
\hline 1,2,3, propenetriol (CAS) & 62.87 & $\mathrm{C} 3 \mathrm{H} 8 \mathrm{O} 3$ & 92 & 1.18 \\
\hline $1,2,3$, propenetriol monoacetate & 25.65 & C5H10O4 & 143 & 2.56 \\
\hline Decanoic acid ethyl ester & 46.38 & $\mathrm{C} 12 \mathrm{H} 24 \mathrm{O} 2$ & 200 & 0.93 \\
\hline $\begin{array}{l}\text { 5-(hydroxyl methyl)-2-(1-methyl-2-imidazolyl)-1 } \\
\text { H benzi }\end{array}$ & 80.66 & $\mathrm{C} 12 \mathrm{H} 12 \mathrm{~N} 4 \mathrm{O}$ & 228 & 5.41 \\
\hline $\begin{array}{l}\text { 9,12-Octadecaadienoic } \\
\text { acid(Z,Z)-,methyl ester }\end{array}$ & 7.01 & $\mathrm{C}_{19} \mathrm{H} 34 \mathrm{O}_{2}$ & 294 & 6.48 \\
\hline $\begin{array}{l}\text { 9,12-Octadecaadienoic } \\
\text { acid, methyl ester }\end{array}$ & 4.25 & $\mathrm{C}_{19} \mathrm{H}_{34 \mathrm{O}_{2}}$ & 294 & 6.48 \\
\hline Linoleic acid ethyl ester & 43.35 & $\mathrm{C} 20 \mathrm{H} 36 \mathrm{O} 2$ & 208 & 17.20 \\
\hline Tetratetracontane (CAS) & 17.29 & $\mathrm{C} 44 \mathrm{H} 90$ & 618 & 13.98 \\
\hline Octadecane 3-ethyl-5-(2-ethylbutyl)- & 2.95 & $\mathrm{C} 26 \mathrm{H} 54$ & 366 & 0.53 \\
\hline Neroine, 4a,5-dihydro- & 2.94 & $\mathrm{C} 18 \mathrm{H} 21 \mathrm{NO} 6$ & 347 & 3.85 \\
\hline Dotriacontane (CAS) & 26.05 & $\mathrm{C} 32 \mathrm{H} 66$ & 450 & 3.85 \\
\hline
\end{tabular}

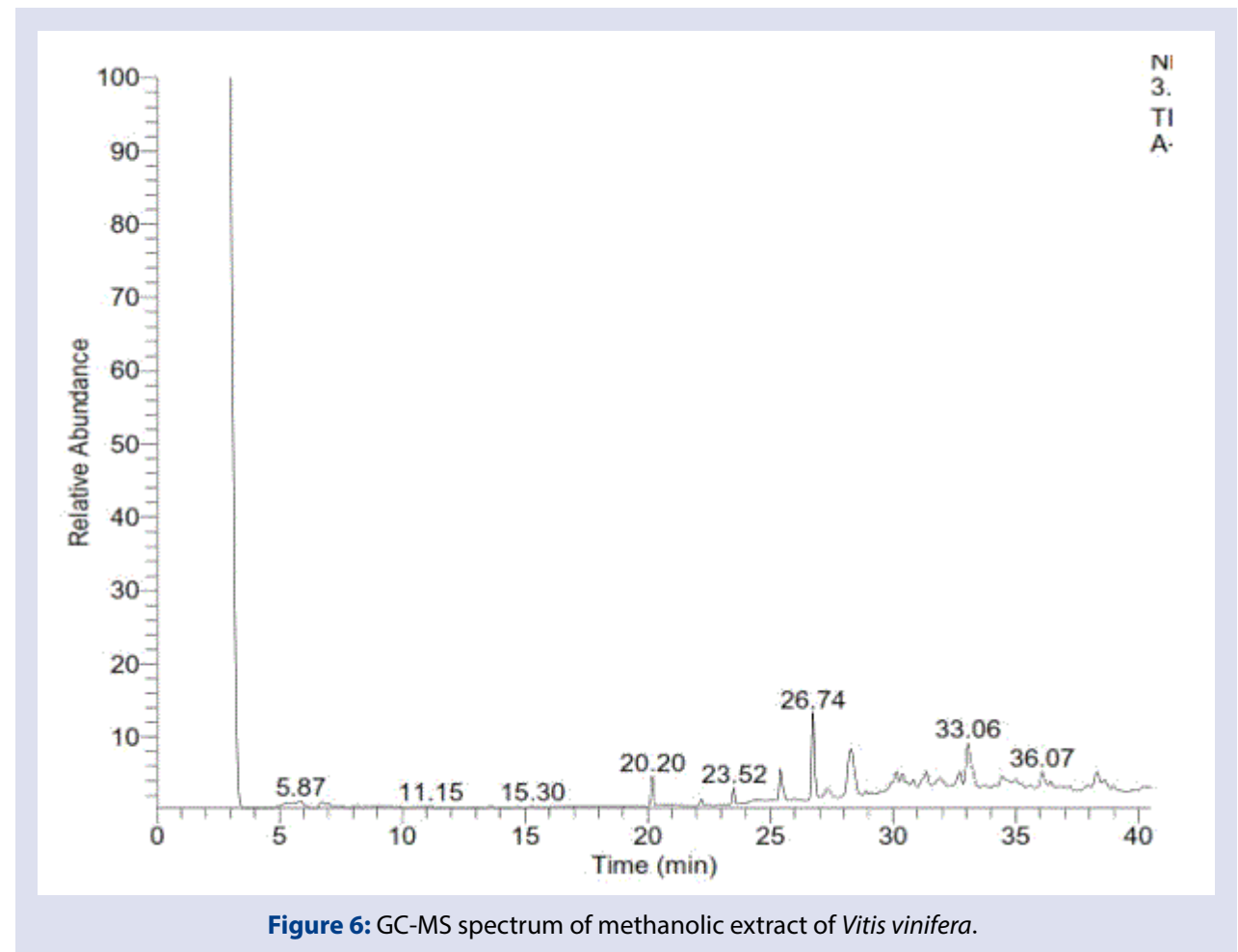

2-(1-methyl -2-imidazolyl)-1 H benzi, Decanoic acid ethyl ester, 1,2,3, propenetriol, monocetate, and Dichloro methyl propane sulfone were detected in the seeds of Vitis vinifera of methanol extract.

\section{Lactate dehydrogenase leak assay}

$\mathrm{LDH}$ is a more reliable and accurate marker of cytotoxicity, because damaged cells are fragmented completely during the course of prolonged incubation with substances. Figure 7 represents that the increasing the concentration of the sample causes significant release of the enzymatic activity. The increase in the concentration results in greater number of cell death. This proves that the Vitis vinifera seeds have the greater effect on the breast cancer cell line MDA MB 231.

\section{DISCUSSION}

Natural products play a major role in cancer prevention and treatment. Nowadays, more than $60 \%$ of anticancer compounds are useful for cancer patients which are obtained from herbal, marine, and microbial sources. Dietary phytochemicals have appeared as advantageous cancer therapeutic agents and they have very less side effects and decreased toxicity compared to synthetic drugs. Alkaloids are capable of modulating key signaling pathways involved in proliferation, cell cycle, and metastasis, making them the chief components of against cancer. ${ }^{15}$ Epidemiological studies suggest that higher intake of flavonoids prevent the risk of developing breast cancer and also chemo-preventive effects in estrogen-dependent or independent breast cancer. ${ }^{16}$ Similarly, biological effect of terpenoids acts as chemo preventive agent on breast epithelial carcinogenesis. ${ }^{17}$ On the other hand, phenolics were tested for their potential anti proliferative and cytotoxic properties in human breast cancer cell lines. ${ }^{18}$ Thus the secondary metabolites have biological effects such as anti-inflammatory, anticancer, contraceptive, and anti-angiogenic properties. ${ }^{19}$

The results of the DPPH 2,2-diphenyl-1-picrylhydrazyl assay suggest that leaves of all Cleome species have potent antioxidant property of scavenging free radicals. These species could be used as a potent 


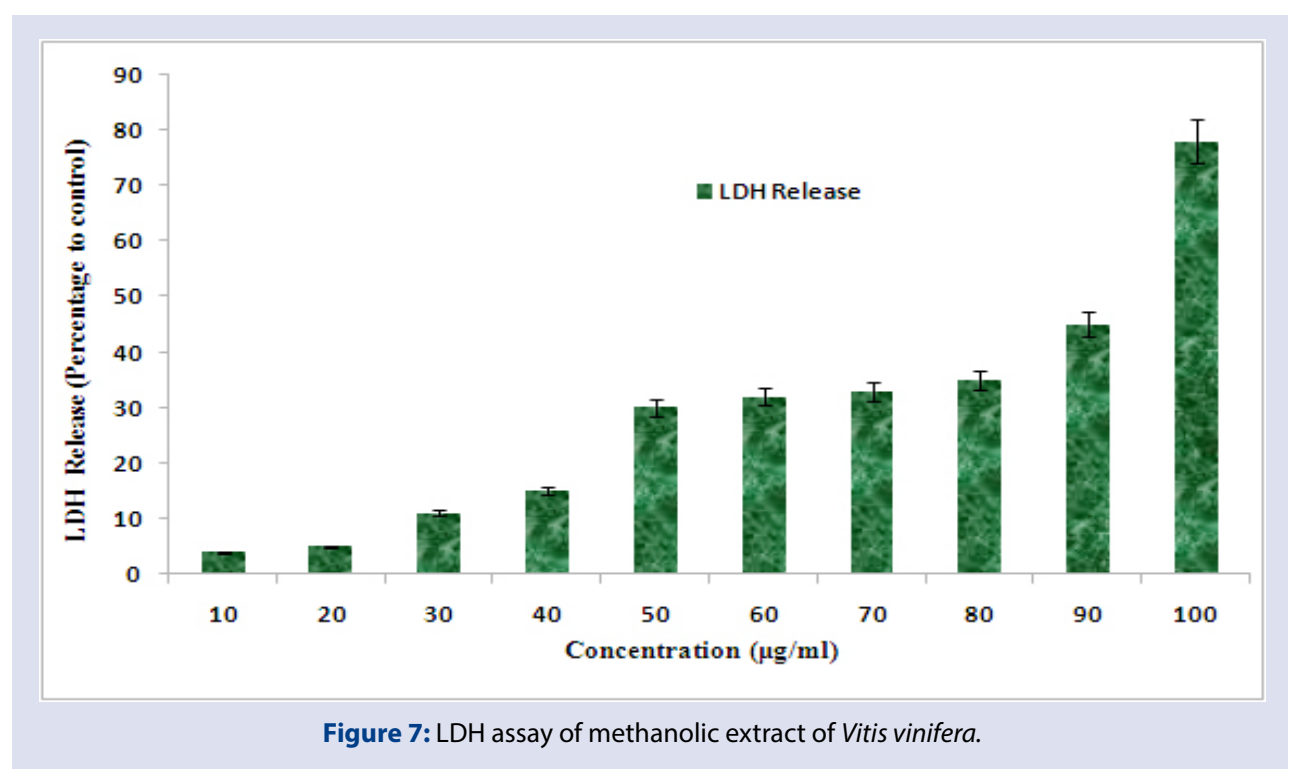

source for the cancer chemo protective therapy. The current results are in accordance with Bowya et al. ${ }^{20}$ They stated that antioxidants are chemical substance that donate an electron to the free radical and convert it to a harmless molecule. It may reduce the energy of the free radical or suppress radical formation or break again propagation or repair damage and reconstitute membranes.

MTT 3-(4,5-dimethylthiazol-2-yl)-2,5-diphenyltetrazolium bromide assay has been most widely used in different cancers, and is sensitive, accurate and efficient in vitro evaluation of anticancer agent. ${ }^{14}$ The biochemical data of the present research clearly shows that the methanolic extract of the grape seed has potential anticancer activity based on $\mathrm{IC}_{50}$ value as mentioned in the result section. The anticancer action of the selected seed might be due to the presence of rich phytoconstituents such as alkaloids, flavonoids and terpenoids etc.

GC Gas Chromatography has played a fundamental role in determining how many components and in what proportion they exist in a mixture. Fragmentation pattern of few compounds were identified in the Vitis vinifera seed were discussed in results. Neroine is the alkaloid compound which is known for its anti-cancer potential. Tetratetracontane which belong to the class of chemical compounds could be employed as an anti-inflammatory, hypocholesterolemic, cancer preventive, hepatoprotective, anti-oxidant agents. ${ }^{21}$ Xiaofeng L et al., ${ }^{22}$ observed that Linoleic acid (LA) inhibited tumor cell growth at high concentrations and also induces cancer cell apoptosis. Dotriacontane identified from GC-MS of Curcuma raktakanda induces Apoptosis and Suppresses Migration in Cancer Cell and also acts as potential antioxidant action. ${ }^{23}$ Further, this also suggested the presence of neroine, tetratetracontane, linoleic acid and dotriacontane, thus provided supporting chemical evidence for the cytotoxic efficacy and antioxidant potential of selected seed.

LDH Lactate Dehydrogenase is a cytosolic enzyme which oxidizes 1-lactate to pyruvate. Leakage of LDH Lactate Dehydrogenase from cytoplasm in the medium is an indicator that there is change in plasma membrane permeability or incidence of apoptosis or necrosis. Extensive reports have documented on medicinal plant extract induced cytotoxicity to cancer cells. The results are accordance with the following study. In the past study, the LDH Lactate Dehydrogenase leakage increased significantly in high dose of when compared aqueous extract of Drosera Indica L. to the control cells. ${ }^{24}$ Hence, the LDH Lactate Dehydrogenase leakage in MDA MB 231 cell line may be due to the cytotoxic nature of the Vitis vinifera seed which confirms the antitumor activity.

\section{CONCLUSION}

In the present study, anti-cancer potential of Vitis vinifera seeds methanolic extract was carried out and showed an appreciable antiproliferative effect on the breast cancer cell line MDA-MB-231. Preliminary screening of the phytoconstituents revealed the presence of alkaloids, flavonoids, terpenoid, steroids and quinine. Methanolic extract of Vitis vinifera seed found to possess good antioxidant and anti-cancer potential. GC-MS analysis revealed the presence of several bioactive compounds, which confirms as anticancer agent. This study confirmed that the seeds possess various phytoconstituents which may contribute its antioxidants and anti-cancer activity. This Vitis vinifera seeds can be subjected to isolation of novel pharmacologically active compound for investigation of anticancer property could be useful for treating infectious disease and metabolic disorders.

\section{ACKNOWLEDGEMENT}

The authors are thankful to the Department of Chemistry and Biosciences, SASTRA Deemed to be University, Srinivasa Ramanujan Centre, Kumbakonam.

\section{REFERENCES}

1. Sonika J, Jaya D, Pankaj KJ, Swaha S, Arjun P. Medicinal Plants for Treatment of Cancer: A Brief Review. Pharmacognosy Journal. 2016;8(2):87-102

2. Shu YY, Wen CW, Feng YJ, Ning SY. Therapeutic Applications of Herbal Medicines for Cancer Patients. Evidence-Based Complementary and Alternative Medicine. 2013;1-15

3. Wu YH, Yi ZC. Natural Phenolic Compounds from Medicinal Herbs. And Dietary Plants Potential Use for Cancer Prevention. Nutrition and Cancer. 2009;62(1):120.

4. https://www.webmd.com/breast-cancer/breast-cancer-types-er-positive-her2positive

5. https://www.who.int/cancer/detection/breastcancer/en/index1.html

6. Boussetta N, Vorobiev E, Le LH, Cordin FA, Lanoiselle JL. Application of electrical treatments in alcoholic solvent for polyphenols extraction from grape seeds. Food Science and Technology. 2012;46(1):127-34.

7. https://www.agrifarming.in/grape-plant-grafting-methods-pruning-and-training.

8. Harbone JB. Phytochemical Methods. 3rd ed. London: Chapman and Hill; 1998.

9. Noraini N, Swee KY Heshu SR, Nur RZ Nadiah A, Nurul EM, Chee WH Mas JM, et al. In vitro cytotoxicity and anticancer effects of citral nanostructured lipid carrier on MDA MBA-231 human breast cancer cells. Sci Rep. 2019;9:1614.

10. Aishwarya $V$, Sheik abdulla S Dheeba B, Renuka R. In vitro antioxidant and anticancer activity of cardiospermumhalicacabum L. Againsteac cell line. Int J Pharm Pharm Sci. 2014;6:8:263-8.

11. Johann SB. C-MET: an exciting new target for anticancer therapy. Ther Adv Med Oncol. 2011;3(1):S3-5. 
12. Syed ZH, Khushnuma M. GC-MS: Principle, Technique and its application in Food Science. INT J CURR SCI. 2014;13:116-26.

13. Ana Flávia LS, Juliana MS, Katiuska T, Diego LR, Heloísa LC, Eliana AV, et al. $\mathrm{LDH}$, proliferation curves and cell cycle analysis are the most suitable assays to identify and characterize new phytotherapeutic compounds. Cytotechnology. 2016;68(6):2729-44.

14. Susithra R, Renuka S, Sivakumar R, Sheik Abdulla SH. Antiproliferative and Antioxidant Activity of Gynandropsis pentaphylla Linn on MCF-7 Cell Line. Int J of Pharmacy and Pharmaceutical Sciences. 2014,6:561-5.

15. Zeina H, Georgio T, Maamoun F, Omar NR, Hala GM. Cytotoxic Alkaloids in the Battle against Cancer. Overview of Molecular Mechanisms. 2017;22:250.

16. Hitomi T, Hiroyuki S, Shunsuke Y, Kayoko S. Breast Cancer and Flavonoids - A Role in Prevention. Current Pharmaceutical Design. 2013;19:6125-32.

17. Thangaiyan R, Anupam B. Terpenoids and breast cancer chemoprevention. Breast Cancer Res Treat. 2009;115:223-39.

18. Indap MA, Radhika S, leenamoti WK, Rao VK. Anticancer activity of phenolic antioxidant against breast cancre cell lines and spontaneous mammary tumors. Indian Journal of Pharmaceutical Sciences.2006;470-476.
19. Wesam K, Karo S, Masoud B, Majid AS, Fatemeh S, Bijan N, HadiZ M Effective Medicinal Plant in Cancer Treatment. Journal of Evidence-Based Complementary \& Alternative Medicine. 2017;1-14.

20. Bowya M, Sivakumar R, Renuka S, Dheeba B. In Vitro antioxidant and antiproliferative activity of Plectranthus amboinicus leaves extract on MCF-7 cell line. Der Pharmacia Lettre. 2016;8(12):1-9.

21. Hamidi N, Ziane L, Djellouli M, Lazouni HA. Chemical characterization by GCMS from the aerial parts of Fagonia longispina (Zygophyllaceae). Asian J Pharm Clin Res. 2016;9(1):175-6.

22. Xiao FL, Guo QH, Hai NY, Qi M, Sheng S, Undurti ND. Colorectal cancer cell growth inhibition by linoleic acid is related to fatty acid composition changes. $J$ Zhejiang Univ Sci B. 2010;11(12):923-30.

23. Mishra S, Verma SS, Rai V, Awasthee N, Arya JS, Maiti KK, et al. Curcuma raktakanda Induces Apoptosis and Suppresses Migration in Cancer Cells: Role of Reactive Oxygen Species. Biomolecules. 2019;23:9(4).

24. Raju A, Arockiasamy JMC, Anita M. In Vitro Antioxidant and anticancer activity studies on Droseraindica L. Advanced Pharmaceutical Bulletin. 2013;3(1);11520.

\section{GRAPHICAL ABSTRACT}

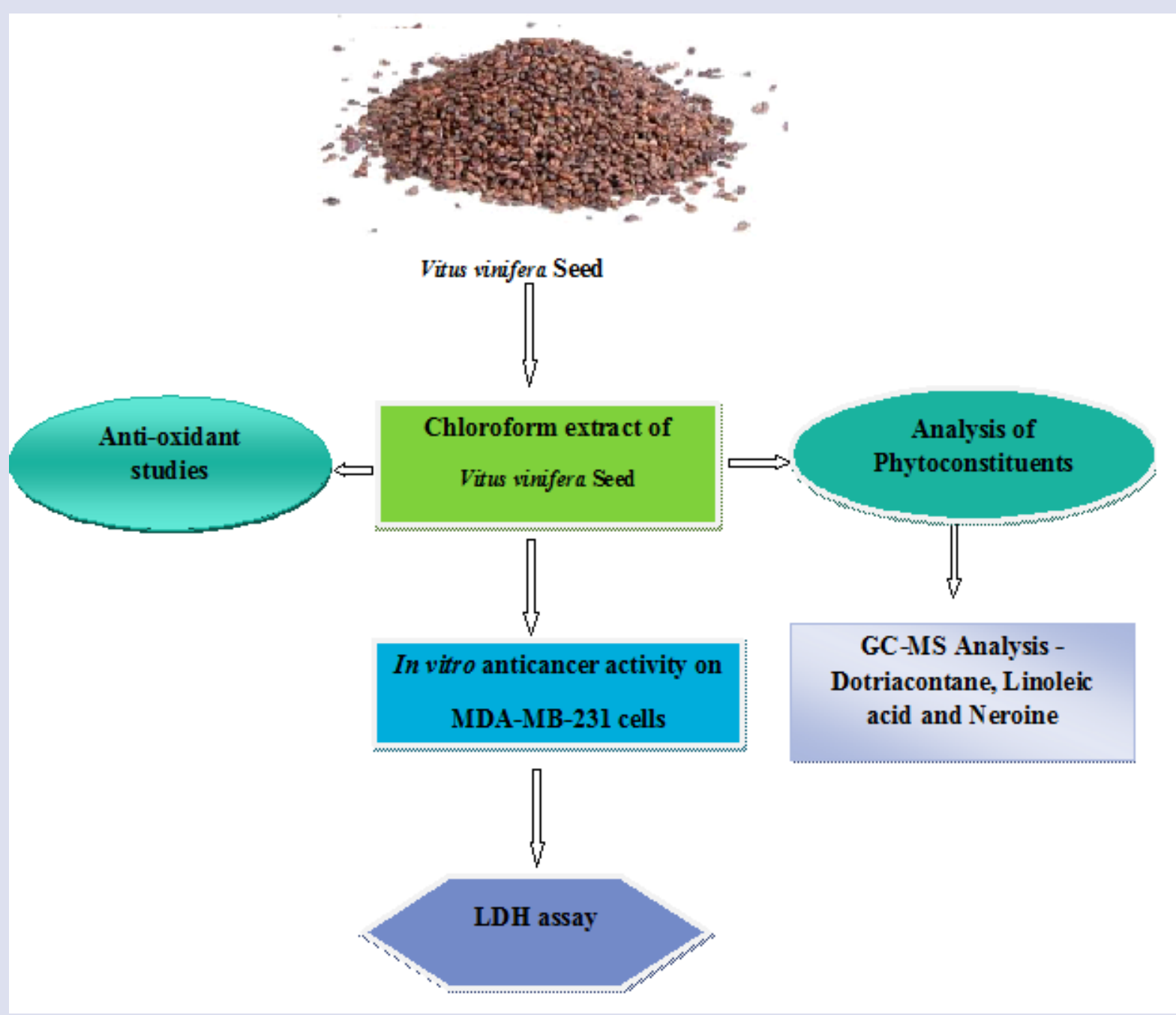




\section{ABOUT AUTHORS}

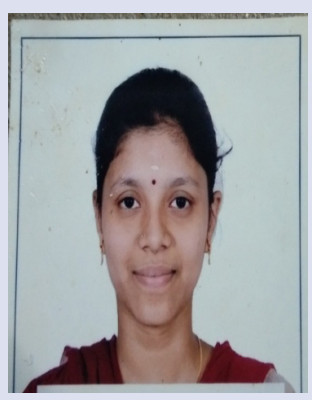

Kiruthika Dhanraj studying M,Sc., Biochemistry in the Department of Chemistry and Biosciences at SASTRA Deemed to be University, Srinivasa Ramanujan Centre, Kumbakonam. Her area of interest includes phytochemistry, Analytical Techniques and Cancer Biology.

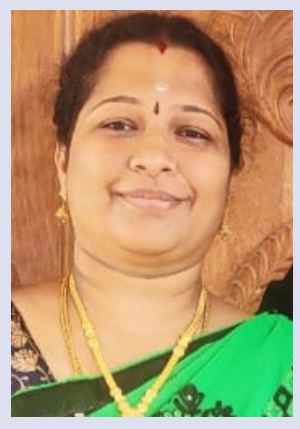

Dr. Renuka Saravanan is working as an Assistant Professor in Department of Chemistry and Biosciences at SASTRA Deemed to be University, Srinivasa Ramanujan Centre, Kumbakonam. She has more than 10 years of teaching experience and 8 years of research experience. Her areas of interest are Cancer biology, Clinical Biochemistry and Herbal Medicine.

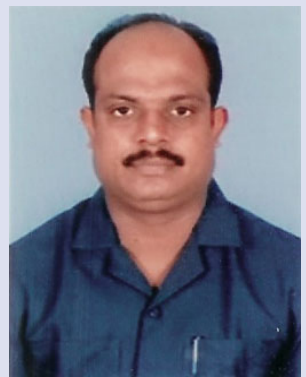

Dr. Sheik Abdulla is working as an Assistant Professor in the Department of Chemistry and Biosciences at SASTRA Deemed to be University, Srinivasa Ramanujan Centre, Kumbakonam. He has more than 20 years of teaching and research experience. His area of interest includes Phytochemistry, Toxicology and Clinical Biochemistry.

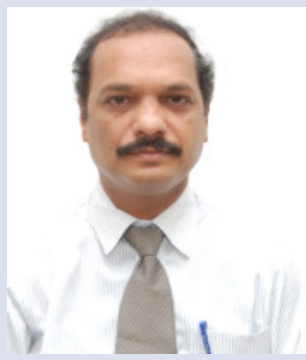

Dr. Sivakumar Ramalingam is working as an Assistant Professor and Head in the Department of Chemistry and Biosciences at SASTRA Deemed to be University, Srinivasa Ramanujan Centre, Kumbakonam. He has Post-Doctoral research experience from Albert Einstein College of Medicine, Yeshiva University, New York and Medical University of South Carolina, USA. He has more than 20 years of teaching and research experience. His area of interest includes Cancer biology and Clinical Biochemistry.

Cite this article: Dhanraj K, Saravanan R, Hameed SAS, Ramalingam S. Evaluation of Anticancer Potential of Vitus vinifera Seed Against Breast Cancer Cells - MDA-MB-231. Pharmacogn J. 2020;12(5):1064-71. 